Зорица Прњат

Географски факултет

Универзитет у Београду
УДК 811'371:004.738.5

доИ https://doi.org/10.18485/

melissa.2016.15.1.ch12

\title{
ПРАГМАТИЧКЕ КАРАКТЕРИСТИКЕ ВИРТУЕЛНЕ КОМУНИКАЦИЈЕ: ГРАЈСОВЕ КОНВЕРЗАЦИЈСКЕ МАКСИМЕ
}

\section{Сажетак}

С обзиром на чињеницу да сви учесници у виртуелној комуникацији користе мање-више идентичну компјутерску технологију и ступају у комуникацију са сличним мотивима, потребама и жељама, могуће је указати на скуп заједничких лингвистичких особина које се јављају у свим облицима овог вида комуникације. Поред појаве великог броја неологизама, непоштовања конвенционалних лингвистичких правила везаних за правопис и интерпункцију, једна од најизраженијих карактеристика виртуелне комуникације је и непоштовање Грајсових комуникацијских максима. Стога ћемо у раду објаснити разлоге због којих се Грајсове комуникацијске максиме (квалитета, квантитета, релевантности и начина) не примењују у виртуелној комуникацији.

Кључне речи: прагматика, конверзацијске максиме, компјутерски посредована комуникација

\section{Увод}

Херберт Пол Грајс је предложио четири основне конверзацијске максиме за које је сматрао да чине основу делотворне употребе језика. Наиме, истражујући језичке појаве из перспективе прагматике, Грајс је сматрао да успех конверзације не зависи само од онога шта је изречено већ и од целокупног става саговорника према интеракцији. (Kristal, 1996, s. 117). Стога је као најважније издвојио следеће максиме:

1. максиму квалитета - према којој говорникови доприноси конверзацији треба да буду истинити. Учесник у комуникацији не 
треба да каже нешто што сматра да је неистинито, нити треба да каже било шта за шта нема одговарајућег доказа;

2. максимурелевантности-према којојдоприноси комуникацији треба да буду релевантни и у складу са циљем комуникације;

3. максиму квантитета - према којој допринос комуникацији треба да буде онолико информативан колико је потребно за циљеве комуникације тј. учесници у комуникацији не треба да саопште ни премало не превише информација;

4. максиму начина - према којој допринос учесника у комуникацији треба да буде јасан, систематичан и кратак. Саговорници, такође, треба да избегавају сваку врсту нејасноћа и двосмислености.

Када је у питању виртуелна комуникација, Дејвид Кристал истиче да се учесници у комуникацији не понашају увек у складу са наведеним принципима, али да већина ипак прећутно прихвата њихову улогу и значај (2001, р. 49).

\section{Примена Грајсових конверзацијских максима у виртуелној комуникацији}

\section{Максима квалитета}

Једна од најважнијих одлика виртуелне комуникације је да учесници у њој могу учествовати анонимно. Ипак, интернет није први масовнимедиј који јеомогућио интеракцијуизмеђупојединаца којижеле да остану анонимни. Пре појаве интернета анонимне конверзације су биле забележене преко телефона и код радио аматера, али су могућности скривања идентитета, посебно у виртуелним световима, чет групама и на друштвеним мрежама без преседана по учесталости и разноврсности. Скривање идентитета кроз лажно представљање омогућава учесницима у комуникацији да се изражавају много слободније у односу на свакодневне комуникацијске навике и свој језички репертоар (Исто. с. 51). Јасно је да оваква врста комуникације носи одређени ризик са собом, а случајеви узнемиравања, вређања 
или агресивности су веома бројни. Питања о идентитету саговорника, која су у комуникацији лицем у лице сасвим излишна, у виртуелној комуникацији представљају неке од почетних размена, где од самих саговорника зависи да ли ће дати истиниту информацију или не.

Стога се може закључити да су у виртуелној комуникацији присутни различити степени истинитости исказа, који варирају од директног лагања, преко ситуације у којој постоји обострана спознаја о претварању, па све до шаљиве игре. Пишући о психологији комуникације на интернету, Патриша Валас износи став “да је чињеница да је веома једноставно лагати и не бити кажњен због тога ...веома значајна одлика комуникације на интернету" (Wallace, 1999, према Crystal, 2001, р. 51). Међутим, Кристал напомиње да је у комуникацији у чет групама и виртуелним световима могуће константно задржати одређени лажни идентитет, због тога што је то у складу са једним од основних принципа функционисања виртуелних светова и чет група. Слично је и у комуникацији на друштвеним мрежама, где поједини учесници креирају лажни идентитет, па чак и више идентитета, под којима обављају комуникацију.

\section{Максима квантитета}

Примери различитих видова виртуелне комуникације показују да се максима квантитета такође често не поштује у комуникацији. Екстремни примери су ситуације у којима учесници у комуникацији заправо уопште не комуницирају. Ова ситуација се у језику интернета означава као 'скривање' (lurking). Учесници у чет групама и друштвеним мрежама који притајени читају поруке осталих учесника, али сами не учествују, то могу чинити из више разлога: код новајлија можда постоји почетна невољност да се упусте у комуникацију, код учесника који истражују, на пример, језик интернета или неки други аспект везан за културу, социјалне односе и понашања на интернету и који само бележе појаве, или код учесника који показују инклинације ка воајеризму.

Следећи пример кршења максиме квантитета је спемовање (енгл. spamming) који представља слање изузетно дугих порука 
које ометају примаоца у комуникацији или једноставно затрпавају његово поштанско сандуче. Као пример можемо навести ситуације када група људи лобира одређеног политичара електронским путем или напада политику одређене странке или компаније. ${ }^{1}$ Овај термин се такође односи и на појаву када се једна иста порука шаље великом броју прималаца као, на пример, када компанија пошаље рекламну поруку свима који се налазе на њеној мејлинг листи. Већина имејл софтвера аутоматски категорише овакве поруке као 'џанк мејл' или 'спем мејл' и одваја их у посебан фолдер поштанског сандучета у који се одбацују нежељене поруке.

Међутим, спем поруке се међусобно разликују како по намерама пошиљаоца тако и по ефекту који имају. Стога, Чарлс Стивал у свом чланку Spam: Heteroglossia and Harassment in Cyberspace (1996) даје класификацију спем порука у оквиру комуникације у чет групама и виртуелним световима. Он наводи да ове поруке, у односу на степен агресивности које пошиљалац испољава, могу бити шаљиве, двосмислене и погубне. Прве се јављају у виду посебних визуелних или аудио ефеката који су програмирани да се појаве у одређеним тренуцима игре (нпр. у игри коју је Стивал проучавао LambdaMOO периодично се чује звоно са сата или крештање папагаја). Ове врсте порука се такође могу видети када један од ликова из игре учини нешто изузетно шаљиво у односу на неког другог учесника (нпр. када један учесник у комуникацији пошаље поруку типа '@nnoy', прималац поруке треба да имитира одређену телевизијску личност). Искусни учесници у играма ову врсту порука сматрају безазленим начином да се привуче пажња. Оне чине саму срж социјалних односа и интеракције у виртуелним световима, а вешта употреба ових порука

1 Порекло термина је везано за једну епизоду серије Monty Python у којој конобарица објашњава гостима кафеа која јела могу поручити: „Well, there's egg and bacon; egg sausage and bacon; egg and spam; egg bacon and spam; egg bacon sausage and spam; spam bacon sausage and spam; spam egg spam spam bacon and spam...". Ова врста хумора у виду досадног понављања, које је на ивици да иритира учеснике у комуникацији, у свету интернета, а посебно чет група и виртуелних светова, означава појаву нежељеног и непотребног слања порука које један учесник намерно упућује како би попунио екран примаоца. Врло често ове поруке могу бити агресивне по својој природи и тада представљају врсту електронског узнемиравања (Crystal, 2001, p. 53; Stivale, 1997, p. 133) 
указује на степен до кога је учесник у комуникацији савладао језик одређене заједнице (Stivale, 1997, р. 135).

Нешто виши степен агресивности показују двосмислене спем поруке које се јављају када један учесник у комуникацији више пута шаље поруку која може да иритира остале учеснике или изазове неког другог играча у игри да уради нешто несмотрено или погрешно због чега ће бити кажњен. Двосмисленост поруке се огледа у чињеници да је намера пошиљаоца поруке нејасна, а ефекат поруке непредвидив.

Трећи и највиши степен агресивности показују погубне спем поруке у којима поједини учесници у комуникацији узнемиравају остале, као код, на пример, сексуалног узнемиравања у стварном животу. Ове поруке обично садрже сексуално експлицитан језик и опис сексуалних радњи, што захтева увођење контролних мера од стране модератора групе (Исто. с. 142).

О спем порукама и начинима спемовања пише и Ли-Елен Марвин у свом чланку Spoof, Spam, Lurk and Lag: the Aesthetics of TextBased Virtual Realities (1996) где износи став да је однос према спем порукама питање укуса. Одређени учесник у комуникацији у виртуелном свету може посматрати спемовање као негативну појаву, а спем поруку сматрати сметњом у комуникацији (посебно када је циљ спем поруке да се употребом претераног броја речи напуни екран примаоца поруке и тиме отежа или потпуно поремети комуникација), док други учесник може спемовање посматрати као забаву. У закључку Марвинова износи мишљење да је поред негативних појава везаних за компјутерски посредовану комуникацију, посебно у оквиру виртуелних светова, потребно одредити и позитивне тј. оне које доприносе успостављању 'идеалног понашања у заједници' $(1996$, р. 9). У такве спадају, на пример, активно учешће у комуникацији и размена кратких, садржајних порука у циљу олакшања комуникације, што указује на жељу учесника да поштују максиму квантитета.

За разлику од спем порука, агресивне и увредљиве поруке везане за одређену тему и упућене одређеном појединцу с намером да провоцирају и изазову вербални рат, означавају се као флејм поруке, а 
слање ових порука као флејминг (енгл. flaming). ${ }^{2}$ Кристал истиче да се међу истраживачима језика компјутерски посредоване комуникације воде полемике око одређења значења термина флејм (енгл. flame). Наиме, разлике у укусима, комуникацијским преференцијама и стиловима разликују се међу учесницима у комуникацији на интернету, као и међу саговорницима у стварном животу. Учесници у комуникацији у чет групама, виртуелним световима и друштвеним мрежама који размењују флејм поруке веома често нису ни свесни језичке агресивности својих порука. Према неким студијама (Crystal, 2001, р. 55) чланови анонимне чет групе размењивали су шест пута више флејм порука (као знак агресивности и непријатељства) него учесници у не-анонимним чет групама. На виђење одређене поруке као флејм поруке утичу и културне разлике, посебно у ситуацијама у којима се поруке размењују између припадника различитих културних заједница. Тако, порука која се једном учеснику у комуникацији, припаднику одређене друштвене заједнице може учинити потпуно невина, може деловати непристојна учеснику који долази из друге заједнице. Такође, степен агресивности флејм порука расте са бројем порука које се размене, па је углавном потребно неколико размена пре него што се релативно благо неслагање претвори у непријатељско супротстављање. Поруке у којима учесници у комуникацији више не говоре о својим темама, већ само размењују вербалне увреде представљају пример очигледних 'ватрених окршаја'.

Међутим, много је теже одредити границу када, на пример, агресивна дебата која се води у чет групама или друштвеним мрежама прелази у флејминг. Вилијам Милард је у свом чланку I Flamed Fraud: A Case Study in Textual Incendiarism (1997) изнео случај једне чет групе у којој је дискусија са одређене теме прешла на један други ниво - на ниво метафлејминга, јер су учесници у комуникацији расправљали да ли је одређена порука флејм порука или не (1997, р. 153). Он је такође уочио, истражујући примере језика који се јавља у чет групама научника и професора универзитета, да је онлајн језик ових група био обележен тензијом, гневом и огорченошћу, што приписује

2 Овај термин је преведен код нас и као 'ватрени окршај'. Упор. Džouns, S. (ur.) Virtuelna Kultura: identitet i komunikacija u kiber-društvu. 
метакомуникативном минимализму самог медијума, временском ограничењу, недостатку стрпљења, кашњењима у одговору на поруку, као и непостојању јасних конвенција понашања у комуникацији на интернету (Исто. с. 147). ${ }^{3}$

\section{Максима начина}

Максима начинасетакођевеомачестонепоштујеукомуникацији на интернету. Многе од порука нису јасне и лако разумљиве, систематичне и кратке, и садрже различите врсте нејасноћа и двосмислености. Краткоћа, по питању дужине реченице, броја реченица у поруци тј. количини текста који се појављује на екрану, представља један од основних императива компјутерски посредоване комуникације. У већини интернет ситуација овај захтев се поштује, осим у комуникацији на вебу где се могу пронаћи многобројни примери веб страна на којима се максима не поштује. Професионални веб дизајнери, као и аутори приручника о веб дизајну стално упозоравају на чињеницу да веб страна мора бити једноставна за навигацију тј. да се између појединих делова веб стране, страна у оквиру једног сајта и сајтова међусобно може без потешкоћа сурфовати. Међутим, многе веб стране још увек праве аматери, јер трошкови израде веб сајта од стране професионалаца могу бити веома високи, што доводи до тога да се максима начина веома често крши.

У примерима других интернет ситуација, такође се може видети да се ова максима често не поштује, али овога пута кршење правила

3 Милард износи сопствено искуство учешћа у двема дискусионим групама: : H-AMSTDY и H-Net (History Net) посвећеним америчким студијама. Теме ових група су међусобна повезаност културолошких студија са америчким студијама и њихово међусобно разликовање. Основна тема дискусије у којој је Милард учествовао тицала се утицаја марксистичког учења на културолошке студије. У тренутку када је један од учесника покушао да одбрани културолошке студије поредећи их са психоанализом, Милард се активно укључио у комуникацију износећи став да се психоанализа показала као друга најгора идеја двадесетог века - херменеутички стерилна и медицински и терапеутски неефикасна, чиме је изазвао дугу и веома жестоку полемику. Многи чланови групе су сматрали да су његове поруке показивале висок степен агресивности и сматрали су их флејм порукама (Millard, 1997, pp. 149158). О понашању на интернету и флејму упор.шире Džouns, S. (ur.) Virtuelna Kultura: identitet i komunikacija u kiber-društvu и Porter, D. (ed.) Internet Culture. 
проистиче из саме природе медијума и начина комуникације. Наиме, у синхроним чет групама постоји висок степен нереда који настаје због великог броја учесника који истовремено комуницирају, а нејасноће и двосмислености у језику везане су за начин писања порука. Брзина комуникације намеће веома велики притисак на аутора поруке да буде селективан у ономе шта ће рећи (због уштеде времена и простора), што веома често доводи до стварања различитих врста нејасноћа.

\section{Максима релевантности}

Према овој максими садржај поруке треба да одговара сврси комуникације. Али,

како Кристал истиче, некада није једноставно одредити сврху комуникације на интернету. У одређеним ситуацијама као, на пример, на вебу када корисник овог интернет сервиса трага за одређеном информацијом или у виртуелним световима када се учесници у игри такмиче ко ће постићи бољи резултат, сврху комуникације је лако одредити. Међутим, у неким другим ситуацијама неколико различитих циљева комуникације могу бити истовремено присутни као, на пример, у имејл поруци у којој учесници у комуникацији размењују информације, али и успостављају одређене социјалне односе (нпр. пошиљалац поруке жели да забави примаоца) (Crystal, 2001, p. 58; Прњат, 2013, с. 47). Такође, постоје примери када учесници у различитим видовима интернет комуникације шаљу поруке не да би заиста комуницирали са неким, већ да би показали да су присутни на интернету тј. да би оставили трага или да би разменом идеја са другим учесницима у истој чет групи или друштвеној мрежи лакше 'разбистрили мисли' и дошли до одређених закључака. Ово се може најбоље видети у разговорима у којима се веома често мењају теме. Такође, у чет комуникацији и друштвеним мрежама учесници могу истовремено дискутовати о неколико тема, што све указује на непоштовање максиме релевантности.

Као што смо већ рекли, убацивање ирелевантних исказа, попут спуф порука, које имају за циљ да забаве, збуне или иритирају, указује на чињеницу да у интернет комуникацији социјални фактори доминирају 
над лингвистичким факторима тј. да саопштавање одређеног садржаја не представља основну сврху комуникације. Социјална функција комуникације на интернету, посебно у чет групама, виртуелним световима и друштвеним мрежама, представља тему којом се велики број истраживача језика интернета бави, а посебно социолингвисти. ${ }^{4}$

\section{Закључак}

Социолингвистичка истраживања језика интернета показала су да учесници у виртуелној комуникацији (компјутерски посредованој комуникацији) веома често крше Грајсове комуникацијске максиме квалитета, квантитета, релевантности и начина. Ово је нарочито изражено у комуникацији у оквиру чет група, виртуелних светова и друштвених мрежа. Разлози се могу наћи у самој природи компјутерски посредоване комуникације која је обележена техничким могућностима уређаја, брзином и пролазношћу комуникације, али и у социјалним факторима попут тежње учесника у комуникацији да остану анонимни, да изразе љутњу и неслагање са саговорницима, да забаве друге учеснике или скрену пажњу на себе. Стога се јављају разни облици „недоличног“ понашања попут спемовања или флемијнга. Међутим, треба нагласити да већина учесника у комуникацији ипак прећутно прихвата улогу и значај комуникацијских максима и тежи да их се придржава.

\section{Литература}

Crystal, David. Language and the Internet. Cambridge: CUP, 2001.

Kristal, Dejvid. Kembrička enciklopedija jezika. Beograd: NOLIT, 1996.

Herring, Susan C. (ed.). Computer-mediated communication: linguistic, social and crosscultural perspectives. Amsterdam: Benjamins, 1996.

Marvin, Lee-Ellen. Spoof, spam, lurk and lag: the aesthetics of text-based virtual realities. Journal of Computer-Mediated Communication 1(2). 1996.

4 О социјалним аспектима компјутерски посредоване комуникације писао је велики број аутора. Упор Porter, D (ed.). Internet Culture; Džouns, S. (ur.). Virtuelna kultura: identitet i komunikacija u kiber drustvu. и Herring, S. C. (ed.). Computer-mediated communication: linguistic, social and cross-cultural perspectives. 
Millard, William. B. I flamed Freud: a case study in teletextual incendiarism. In Porter (ed.). Internet Culture. New York and London: Routledge, 1996: 149-158.

Porter, D. (ed.). Internet Culture. New York and London: Routledge, 1996.

Прњат, Зорица. Језик имејла. Речи V, 6, (2013): 44-54.

Stivale, Charles. Spam: heteroglossia and harassment in cyberspace. In Porter (ed.). Internet Culture. New York and London: Routledge, 1996: 133-144.

Džouns, Stiven. Virtuelna kultura: identitet i komunikacija u kiber društvu. Beograd: XX vek, 2001.

Wallace, Patricia. The psychology of the Internet. Cambridge: CUP, 1999.

\title{
Zorica Prnjat
}

\section{PRAGMATICS OF VIRTUAL COMMUNICATION: GRICE'S CONVERSATIONAL MAXIMS}

\begin{abstract}
Summary
Considering the fact that all participants in virtual communication (computermediated communication) use more or less identical computer technology and engage in communication with similar motives, needs and interests, it is possible to distinguish a set of common linguistic characteristics that occur in all forms of virtual communication. In addition to the appearance of a large number of neologisms, disrespect of conventional linguistic rules related to spelling and punctuation, one of the most striking characteristics of virtual communication is disregard of Grice's conversational maxims. Therefore, in this paper, we will explain the reasons why Grice's conversational maxims (maxim of quality, quantity, relevance and manner) are not applied in virtual communication.
\end{abstract}

Key words: pragmatics, conversational maxims, computer-mediated communication, virtual communication 